\title{
Comentário ao Posfácio de Liev Tolstói a sua novela A Sonata a Kreutzer
}

\author{
Natalia Quintero
}

\begin{abstract}
Resumo: O trabalho que segue é a apresentação de uma proposta de tradução direta do russo para o português do posfácio, até agora, inédito no Brasil, que Liev Tolstói escreveu para sua obra A Sonata a Kreutzer. A tradução está precedida por um comentário em que mostramos a importância que o próprio Tolstói deu a esse trabalho, e de que maneira esse texto trą respostas do autor aos questionamentos dos leitores acerca da abstinência sexual pregada pelo protagonista de sua novela. Salientamos a importância que tem o conceito tolstoiano de "ideal", não apenas como chave de leitura da obra, senão como ideia estrutural do conceito de amor universal que percorre toda a obra artística e o pensamento do autor russo.
\end{abstract}

Palavras-chave: Liev Tolstói; Sonata a Kreutzer; conceito de ideal; amor universal

A novela $A$ Sonata a Krentžer é uma obra que não deixa indiferente quase nenhum leitor. Foi assim desde sua primeira aparição em $1889^{1}$. Desde então, podemos afirmar quase sem temores que é uma das obras mais polêmicas de Liev Tolstói. Tão logo foi publicada, gerou uma onda de reações que pode ser constatada por meio de documentos como cartas e anotações de diário do autor e, nos dias de hoje, por artigos acadêmicos e de jornais que tratam dessa polêmica ${ }^{2}$. A novela conta a história de um marido que, tomado por ciúmes,

1 A primeira versão publicada de $A$ Sonata a Kreutzeré é de 1889. Contudo, Tolstói fez ainda correções na obra, além de redigir o posfácio para a mesma. Essa versão, seguida pelo posfácio, apareceu em 1891, e é considerada a variante definitiva da obra. A partir dela foram feitas as reimpressões sucessivas e as traduções e edições em outras línguas.

2 Vide, por exemplo, o artigo "O que quer de mim essa música" de Samuel Titan Jr., surgido a propósito do lançamento de uma nova edição da novela em 2008. Também o artigo "Mulher de Tolstói ganha voz própria" de William Grimes surgido na seção "Ilustrada" da Folha de São Paulo em 2014, 
mata sua esposa. Esse motivo simples, mas impactante, serve ao autor para tecer uma trama de reflexões, que incluem, por um lado, um questionamento da influência que exerce a música no ser humano e, portanto, de seu papel na sociedade e, por outro, da posição da mulher na família, na sociedade e, por fim, das relações entre homem e mulher, em que a vivência da sexualidade é apresentada, intencionalmente, sem quaisquer enfeites românticos, e mostrada como detonante de uma tragédia.

É justamente o tratamento da questão sexual o que vem inquietando várias gerações de leitores. Muitas vezes o grande conhecedor e tradutor da obra de Tolstói, professor Boris Schnaiderman, manifestou sua admiração pela arte de Liev Tolstói, mas também seu desacordo com as ideias do autor russo. Precisamente, ele abre o posfácio que escreveu para sua tradução dessa obra com as palavras "O leitor atual de A Sonata a Krentz̧er (1891) vive com certeza uma situação muito contraditória. Realmente, não dá para aceitar em nossos dias o que Tolstói diz aí sobre a relação entre os sexos” (SCHNAIDERMAN, 2013, p. 107).

Não apenas "em nossos dias", os leitores ficam perplexos pelo que parece uma prédica de Tolstói contra as relações sexuais e contra toda a organização, na sociedade, das relações entre homens e mulheres. A novela não se limita apenas à questão do problema da sexualidade como um pecado, senão apresenta, por meio da fala de Pózdnichev, protagonista da obra, uma visão extremamente instigante acerca da posição da mulher na sociedade ${ }^{3}$, como um ente vingativo que submete o homem por meio da sedução, pelo fato de não desfrutar de direitos iguais aos

ou as declarações da professora Aurora Bernardini no capítulo 90 do programa "Literatura Fundamental" da Univesp.

3 A questão da mulher na obra e pensamento de Liev Tolstói é um problema complexo que não se limita apenas à sexualidade. É opinião comum que, apesar do papel relevante que as personagens femininas exercem na criação tolstoiana, a visão do autor sobre as mulheres é machista e até misógina, pois, em geral, as personagens femininas com destinos felizes, são aquelas que, após uma experiência de desvio do modelo tradicional de retidão moral feminina, assumem seu papel de donas de casa e esposas amorosas e fiéis, encontrando nisso a felicidade (caso de Natacha Rostova em Guerra e Paz, ou Kitty em Anna Kariênina), ao passo que aquelas que rejeitam seu papel de mães e esposas são "castigadas" com a morte (Anna Kariênina). Em relação à esposa de Pózdnichev, personagem feminina central da novela A Sonata a Kreutzerer, a opinião dominante não é diferente (vide, por exemplo o artigo de Teresa Martins Marques que afirma que "a Sonata é uma confissão agressiva, virulenta e panfletária contra a mulher. Tem muito de um ajuste de contas contra a sua própria mulher, Sónia, e com a mulher em geral. Não lhes perdoa o facto de tanto o terem tentado, ao longo da vida, nem de tanto ter cedido à tentação, apesar da luta”). Contudo, outra leitura em relação ao destino dessas mulheres "castigadas", pode ser feita a partir das noções de amor e igualdade que Tolstói trata, por exemplo, no próprio posfácio à Sonata a Kreutz̧er, em outras de suas obras artísticas e em textos documentais. $\mathrm{O}$ tema da mulher no pensamento tolstoiano merece um estudo separado, que não podemos tratar no espaço deste comentário. 
do homem "no convívio entre os sexos" (TOLSTÓI, 2013, p. 34). E assim parece que, para livrar-se desse domínio destruidor, Pózdnichev chega à conclusão de que a melhor solução é a abstinência sexual.

Logo, os primeiros leitores ficaram preocupados com uma doutrina que parecia querer conduzir à extinção da humanidade. Já os leitores contemporâneos, mostram-se incomodados com o que poderia considerar-se como uma visão retrógrada da sexualidade apresentada pelo escritor. Contudo é unanimidade a percepção de que a novela está escrita com uma poderosa e convincente força, o que desperta nos leitores a sensação de impossibilidade de rejeitar, de forma taxativa, o que parece um absurdo: colocar-se a castidade como um objetivo de vida. O próprio Boris Schnaiderman afirmou, de maneira certeira, que é característica do estilo de Tolstói "a veemência, a capacidade de defender com vigor, do modo mais direto, o que ele considerava justo” (SCHNAIDERMAN, 1983, p. 13).

Também Vladímir Nabókov, que por muitos anos dedicou-se ao ensino, análise e difusão da literatura russa, manifestou em suas conferências, reunidas posteriormente em forma de ensaio, que na criação tolstoiana é difícil separar o artista do pensador, o gênio do pregador. Contudo, pondera Nabókov, não devemos esquecer que a literatura não é organização de ideias, mas organização de imagens. Com isso, o autor quer salientar que o que diferencia o discurso literário de outras formas de discurso é, precisamente, o uso singular de determinados recursos, nomeadamente, das imagens criadas a partir de metáforas, comparações, símiles, além do uso do tempo e da descrição para fins específicos: "a palavra, a expressão, a imagem é a verdadeira função da literatura” (NABÓKOV, 2015, p. 218). Nesse mesmo sentido, já em 1917, Viktor Chklovski, em seu ensaio "A arte como procedimento", em que trata das diferenças entre linguagem cotidiana e linguagem artística, apresenta um dos conceitos que têm sido mais produtivos para o estudo e compreensão da arte de Tolstói - o estranhamento (ostranienie - остранение).

De acordo com Chklovski, a linguagem artística "desautomatiza"4 a percepção dos objetos. Essa desautomatização acontece por meio de "procedimentos

4 Deciframos e entendemos o conteúdo de um texto sem realmente ler cada uma das letras que compõem as palavras. Identificamos as palavras e captamos o significado, porque uma parte delas, por exemplo suas letras iniciais, nos é suficientemente conhecida para identificar o todo. Por isso, podemos ler um texto, mesmo que as letras estejam em desordem, sem prestarmos atenção especial a cada palavra, porque as palavras em si não têm importância, mas a mensagem que se transmite por meio delas. Chklovski chama esse processo de "automatização da língua". O fenômeno é próprio da linguagem cotidiana. Diante de objetos representados por meio da linguagem cotidiana, o leitor ouvinte ou espectador é levado ao "reconhecimento" do objeto representado. Já diante de um objeto representado artisticamente, o leitor-espectador vê o objeto cotidiano sob uma forma nova, e o desconhece. Isto é, o artista, por meio de seus procedimentos singulares de linguagem, provoca o "estranhamento". 
particulares, cujo objetivo é assegurar para estes objetos uma percepção estética" (CHKLOVSKI, 1976, p. 41). Um dos meios mais comuns para provocar a desautomatização da linguagem é o estranhamento. Chklovski mostra que é esse um dos procedimentos mais utilizados por Liev Tolstói ao longo de toda sua produção artística, trazendo exemplos extraídos de Guerra e paz, Ressurreição, A sonata a Kreutzer e, de forma mais detalhada, de Kholstomer. De acordo com Chklovski, o procedimento de estranhamento usado por Tolstói consiste em não chamar as coisas por seu nome habitual, mas descrevê-las como se estivessem sendo vistas pela primeira vez, e os acontecimentos, como se estivessem ocorrendo pela primeira vez (CHKLOVSKI, 1976, p. 46). Por outras palavras, o estranhamento é uma espécie de "descontextualização" - tirar os objetos comuns de seu âmbito cotidiano para obrigar-nos a observá-los, a prestar atenção a eles, como se nunca antes os tivéssemos visto. É graças a essa forma singular de apresentar os objetos habituais, por meio de um uso singular da descrição e das figuras de linguagem, que eles adquirem aos nossos olhos um caráter inusitado. Em $A$ sonata a Krentzerer, todo o discurso de Pózdnichev está construído por meio desse procedimento. Assim por exemplo, se o habitual em relação à descrição de um homicídio é a expressão grave, séria, trágica, em $A$ sonata a Kreutžer temos, junto a esses elementos, a irrupção inesperada de um elemento desconcertante: o assassino está de meias e sente-se, por isso mesmo, ridículo, e impedido de agir como the parece que seria o esperado nessa situação: "Eu quis correr atrás dele, mas lembrei-me de que seria ridículo correr de meias atrás do amante de minha mulher, e eu não queria ser ridículo, queria ser assustador. Não obstante a fúria terrível em que me encontrava, lembrei-me o tempo todo da impressão que estava causando aos demais, e esta impressão até me dirigia em parte" (TOLSTÓI, 2013, p. 98). Depois vem a descrição do assassinato em si, e todas as reflexões que se passam pela cabeça de Pózdnichev ao perceber que, realmente, ele foi capaz de matar sua esposa. Então pede que avisem à polícia e por fim, adormece. Quando a irmã da esposa vem dizer-lhe que ela está morrendo, que é preciso que ele vá para junto dela na hora derradeira, Pózdnichev sente a ironia de sua situação e, de novo, está mais preocupado com a possibilidade de seu ridículo, do que com a tragicidade do momento:

"Ir para junto dela?" - formulei esta pergunta a mim mesmo. E imediatamente respondi que era preciso ir, que, provavelmente sempre se faz assim, que numa ocasião em que um marido matou, como eu, a mulher, é preciso sem falta ir para junto dela. "Se é assim que se faz, tenho que ir" [...] "Agora, haverá frases, caretas, mas eu não cederei a elas" - disse comigo.

- Espere, - dirigi-me à irmã -, é estúpido ir sem botas, deixe-me calçar pelo menos os sapatos (TOLSTÓI, 2013, p. 102). 
De forma semelhante, ao longo da novela Tolstói transforma, por meio de seu personagem Pózdnichev, o que é habitual em inusitado e então a autoridade da ciência e da medicina é vista por seu personagem como feitiçaria, o caráter natural do sexo como um vício, ele compara o domínio da mulher sobre o homem com o papel dos judeus no comércio, e chama o assassinato da esposa de "episódio crítico", tirando-lhe com isso todo o peso com que habitualmente um ato como esse é percebido e representado. Enfim, como diz Chklovski, "qualquer um que conheça bem Tolstói, pode encontrar centenas de exemplos desse tipo" (CHKLOVSKI, 2017, p. 6). Mas o importante é compreendermos que em Tolstói, o uso dos procedimentos literários está subordinado a um plano em que a forma de representação está indissoluvelmente unida à ideia e em função dela $a^{5}$ :

Essa capacidade de ver as coisas fora de seu contexto fez com que Tolstói, em suas últimas obras, ao examinar dogmas e rituais, usasse também o método do estranhamento (ostranienie - ocmpaненue) para descrevê-los, substituindo as palavras habituais de uso religioso por seus significados de uso comum; disso resultou alguma coisa estranha, monstruosa, que muita gente tomou com toda sinceridade, como uma blasfêmia que ofendeu profundamente a muitos. No entanto, isso não era outra coisa além do mesmo procedimento por meio do qual Tolstói percebia e relatava tudo o que o circundava. As percepções tolstoianas abalaram-lhe a fé, ao atingir aquelas coisas que, por muito tempo, ele não quisera tocar (CHKLOVSKI, 2017, p. 6. Tradução de Natalia Quintero) ${ }^{6}$.

Assim, insatisfeito pela impressão de não ter conseguido expressar direito em sua novela aquilo que lhe parecia essencial, Tolstói começou logo a pensar em um texto complementar, um posfácio, quase imediatamente depois de concluir a redação de $A$ sonata a Krentzer, em novembro de 1889 . De acordo com a pesquisa

5 Nesse aspecto é extremamente interessante a análise nabokoviana segundo a qual "um traço peculiar do estilo de Tolstói reside no fato de que, em geral, suas comparações, símiles e metáforas não são usados para fins estéticos, e sim éticos. Em outras palavras, suas comparações são utilitárias, funcionais. São empregadas não para realçar as imagens, para dar novas cores à nossa percepção artística de determinada cena; são empregadas, isto sim, para enfatizar um argumento moral” (NABÓKOV, 2015, p. 255).

6 Всякий, кто хорошо знает Толстого, может найти в нем несколько сот примеров, по указанному типу. Этот способ видеть вещи выведенными из их контекста, привел к тому, что в последних своих произведениях Толстой, разбирая догматы и обряды, также применил к их описанию метоА остранения, подставцяя вместо привычных слов религиозного обихода их обычное значение; получилось что-то странное, чудовищное, искренно принятое многими как богохульство, больно ранившие многих. Но это был все тот же прием, при помощи которого Толстой воспринимал и рассказывал окружающее. Толстовские восприятия расшатали веру Толстого, Аотронувшись до вещей, которых он Аолго не хотел касаться]. 
realizada pelos acadêmicos que prepararam a primeira edição das Obras Completas de Tolstói em noventa volumes, naquela época, um dos principais interlocutores do autor era seu colaborador e posteriormente editor Vladímir Tchertkov. Pela correspondência entre eles, parece que Tchertkov sugeriu a Tolstói que escrevesse um posfácio explicando o que o autor pensava sobre o tema da novela. Em resposta, Tolstói disse que já tinha começado a redação desse texto. Ele trabalhou intensamente na escrita de seu posfácio à Sonata a Kreutzerer e, mesmo assim, a conclusão do mesmo, entre diversas variantes e correções, levou praticamente um ano. $\mathrm{O}$ trabalho não foi fácil porque, além de seus próprios questionamentos permanentes acerca do tema da obra, Tolstói tinha também a preocupação de responder aos questionamentos de seus leitores. De fato, apesar da insistência de Tchertkov para que Tolstói escrevesse um posfácio, ou pelo menos algum esclarecimento em relação à defesa da castidade absoluta, Tolstói sentiu-se mais encorajado a dar continuidade à redação do texto graças às inquietações que lhe manifestavam os leitores. Assim escreve Tolstói em uma cópia de uma carta enviada a Tchertkov, em janeiro de 1890: "Fala-se de cinismo, indecência, pessimismo, soturnidade deste relato” (TOLSTÓI, 2006, vol. 27, p. 627. Tradução de Natalia Quintero) ${ }^{7}$. Ao que parece, Tolstói recebeu uma carta de um desconhecido, identificado como V. P. Prókhorov que, em essência, estava preocupado com considerações de Tolstói em relação ao casamento, e pede-lhe a gentileza de escrever-lhe qual é a ideia essencial da novela $A$ Sonata a Krentžer. O leitor, que se dirige a Tolstói em tom muito respeitoso, diz entender que talvez ele não tenha tempo para satisfazer o pedido, ou até ache que é inútil responder a carta. Contudo, insiste em que a questão é muito importante para ele, e que da resposta de Tolstói, poderiam depender decisões capazes de mudar o curso de sua vida. Em relação a essa carta, no dia 11 de março de 1890, Tolstói escreve no seu diário: "Pensei no posfácio em forma de uma resposta à carta de Prókh[orov]” (TOLSTÓI, 2006, vol. 51, p. 26. Tradução de Natalia Quintero) ${ }^{8}$. Tolstói não chega a realizar o plano de escrever o posfácio a sua Sonata como uma resposta à carta de Prókhorov, mas isso não significa que ignorasse os pedidos ou perguntas de seu público. Simplesmente, não era possível atender a cada um, mas tentou considerar em seu texto as questões que pareciam mais pungentes para a maioria dos leitores. Por isso, já em abril de 1890, escreve a Tchertkov, informando que não pretende fazer mais correções no texto: “[...] não é que eu esteja satisfeito com o posfácio. Tanto a forma da narrativa, como a ordem e o tamanho não estão certos. Mas as ideias lá expressas estão certas e

7 [говорится о цинизме, неприличии, о пессимизме, мрачности этого рассказа]

8 [Аумал о послесловии в форме ответа на письмо Прох[орова]] 
são sinceras. E eu as revelei com a maior intensidade e alegria" (TOLSTÓI, 2006, vol. 27, p. 631. Tradução de Natalia Quintero) ${ }^{9}$. Todavia, Tolstói ainda fez correções e mudanças até novembro desse ano, com atenção especial ao problema do casamento, que preocupava tanto a Tchertkov, como a muitos outros leitores ${ }^{10}$.

Com isso queremos mostrar que Tolstói sentia-se profundamente envolvido com a opinião e as preocupações de seu público, era consciente do espanto que a defesa da abstinência sexual despertava em muitas pessoas, e se hoje pudesse ler as inquietações dos leitores contemporâneos em relação a sua novela, talvez continuasse respondendo, modificando seu posfácio e "buscando a expressão mais adequada", a fim de que suas ideias por fim ficassem claras. Como quer que seja, a resposta às inquietações comuns aos primeiros leitores e a muitos leitores contemporâneos está ali, no posfácio. É por isso que, na nossa opinião, o posfácio deveria ser compreendido como parte integrante da obra $A$ Sonata a Kreutzerer, da mesma forma que o epílogo de Guerra e paz, com toda sua carga filosófica, é uma parte inseparável do romance. O destino do posfácio de Tolstói a sua novela não tem sido fácil. A existência de várias versões manuscritas incompletas do texto tem dificultado o seu estabelecimento definitivo como o pensou seu autor. Mesmo assim, existem traduções para várias línguas (inglês, espanhol, alemão), mas nem sempre as edições de $A$ Sonata a Krentzer são acompanhadas pelo posfácio. No caso brasileiro, o texto é, até agora, inédito.

O posfácio de Liev Tolstói a sua Sonata a Kreutzeré uma peça fundamental para a compreensão da produção artística e do pensamento do autor. Nele, Tolstói define com insistência (por meio de repetições de palavras que caracterizam o estilo tolstoiano, como pensa Schnaiderman), com veemência (por meio de exemplos e comparações extremas), e também com mestria artística, aquilo que pode ser a chave para a compreensão, não apenas da defesa furiosa da abstinência sexual na boca de Pózdnichev, senão também de boa parte do pensamento tolstoiano: trata-se

9 [я не то что доволен послесловием. И форма изложения, и порядок, и мера все неверно. Но мысли, высказанные там, верны, искренны, и я с величайшим напряжением и радостью открывам их]

10 A postura inflexível de Tolstói em relação ao casamento é uma resposta ao insistente pedido de Tchertkov, de que repensasse a questão, pois ele considerava que a proposta da castidade absoluta, ao invés de atrair, podia afastar as pessoas do caminho de Cristo. Tolstói então escreve a seu amigo e colaborador: "Eu não consegui fazer no posfácio aquilo que o senhor quer, e no que insiste tanto, como espécie de reabilitação do casamento honesto. Não existe tal casamento. Aliás, o senhor vai ver” (TOLSTÓI, 2006, vol. 27, p. 631. Tradução de Natalia Quintero). [я не мог в «послесловие» слелать то, что вы хотите и на чем настаиваете, как бы реабилитацию честного брака. Нет такого брака. Но, впрочем, вы увиАите] 
da concepção de "ideal"; para Tolstói, o ideal é um modelo que cada pessoa deve colocar diante de si, para chegar cada vez mais adiante em seu desenvolvimento como ser humano. Quanto mais elevado o ideal, mais longe chegará a pessoa em seu crescimento. E, o mais importante, a condição obrigatória para que um ideal seja tal, é o fato de ser irrealizável. Exatamente assim é a doutrina de Cristo. Nenhum ser humano pode encarnar, na vida real, todas as características atribuídas a ele, mas se Cristo fosse o modelo seguido pelas pessoas, então, sem dúvida, haveria seres humanos cada vez melhores.

Essa noção é essencial para compreender o sentido que dava Tolstói para a aspiração à castidade, não como uma norma de vida, como uma imposição ou como uma exigência artificial e absurda, ainda mais por vir de um homem que, em conformidade com os fatos (Tolstói foi pai de 13 filhos), predicava, mas não praticava. A abstinência sexual é colocada por Tolstói em seu posfácio apenas como um meio para aproximar-se, o máximo possível, da realização do amor universal, que constitui um dos alicerces de seu pensamento. Esse conceito de amor que atravessa toda a produção, tanto artística, como não ficcional de Tolstói, está presente desde os primeiros anos de trabalho do jovem Tolstói, de acordo com as anotações de seu diário ${ }^{11}$.

O problema do amor permanece vivo no pensamento de Tolstói durante toda sua vida, e a leitura do posfácio à Sonata a Krentz̧er revela bem que o ideal proposto por ele não é o da castidade e muito menos o da extinção da espécie humana, mas o amor universal, que é o amor ao próximo, seja ele quem for, de acordo com os ensinamentos da doutrina de Cristo. É evidente, pelas próprias citações que traz o autor em seu posfácio, que a leitura dos Evangelhos teve uma influência determinante em sua concepção definitiva da noção de amor. Ele concebia o amor desinteressado por todos os seres como a aspiração mais elevada que podia colocar-se o ser humano. Ao mesmo tempo, para Tolstói era uma aspiração inatingível (ele se perguntava, por exemplo, quem teria forças para amar um assassino ou estuprador) e, por isso mesmo, ideal. A principal virtude da dificuldade desse ideal é que ele obriga, quem o aceitar, a viver uma vida cada

11 A primeira definição do conceito de amor em Tolstói, aparece em 1847, no primeiro ano em que o autor começa a escrever seu diário. Nessa etapa de sua vida, a definição e solução de problemas éticos ocupa um lugar central em suas preocupações. Entre elas, a concepção do ser humano como dividido em corpo e alma e o desejo de que a vontade se torne uma força soberana sobre o corpo conduzem a uma definição singular da vivência do amor por etapas, que vão do amor carnal, no estágio mais baixo, quando o corpo ainda não está dominado pela força de vontade, ao amor universal, no estágio mais elevado. Esse primeiro conceito de amor é repensado e reelaborado por Tolstói ao longo de sua vida, e está representado em várias de suas obras artísticas. 
vez melhor para si próprio e para todos os circundantes, a fim de aproximar-se, cada vez mais, da materialização do ideal. Por outro lado, a castidade era entendida por Tolstói como um mecanismo para dedicar toda a atenção e todas as forças para cuidar do próximo e assim, servir a Deus. O fim do mundo e da espécie humana seriam apenas uma consequência da superação do amor próprio em prol da humanidade. Porque o amor carnal não é mais que a satisfação da vontade pessoal de prazer. Se a pessoa conseguir colocar o bem comum antes da satisfação pessoal, não haverá mais união carnal, e será cumprida a profecia de Isaías ${ }^{12}$. Tolstói afirma que a desaparição da espécie humana não é nem um ideal, nem uma notícia nova, mas apenas um dogma tanto da ciência como da fé. Os homens da ciência estão convencidos de que o esfriamento do sol é uma realidade ineludível e, com ele, virá o fim da espécie humana. Mas o que incomoda seus leitores, de acordo com Tolstói, é a ideia, ou até o temor, de que a espécie humana possa desaparecer em decorrência da materialização do ideal de vida moral que Cristo legou à humanidade.

Apesar do esforço de Tolstói em esclarecer no posfácio a ideia fundamental de sua novela - o conceito de ideal -, as opiniões e exemplos ali contidos não fizeram mais que reafirmar o desconcerto dos leitores e atiçar as críticas ${ }^{13}$. Contudo, como afirma Schnaiderman em seu posfácio à Sonata, "a novela nos arrasta com seu tom arrebatado, com a exaltação e o patético desse texto" (SCHNAIDERMAN, 2013, p. 107).

Oferecemos a tradução do posfácio à Sonata a Krentzer como uma tentativa de superar e compreender o porquê do espanto diante de uma obra que, por mais que contradiga nossas próprias concepções, não podemos jogar fora como se fosse o delírio de um desequilibrado. Como afirma Boris Eikhenbaum na introdução a seu ensaio O jovem Tolstói (Molodoi Tolstoi) "O fenômeno literário está vivo enquanto ele não é compreendido, enquanto ele surpreende. A crítica surpreende-se, a ciência compreende" (EIKHENBAUM, 1987, p. 35. Tradução de Natalia Quintero) $)^{14}$.

\section{Isaías 2:4; Miquéias 4:1-5.}

13 Tolstói escreve em seu diário de 11 de fevereiro de 1891 "Nestes dias, nos jornais só tem artigos injuriosos. De Suv[orin], sobre o posfácio” (TOLSTÓI, 2006, vol. 52, p. 6. Tradução de Natalia Quintero) [За эти Ани были всё статьи в газетах ругательные. О послесл[овии] Сув[орина]. De acordo com nota da edição comemorativa das obras completas de Tolstói em noventa volumes, Alexei Serguiêevitch Suvorin (1834 - 1912) publicou no jornal "Novoe vremia" (Tempo novo) do dia 5 de fevereiro de 1891 o artigo "Malenkoe pismo" (Pequena Carta) em que critica o posfácio à Sonata a Krentzer.

14 [художественное явление живо до тех пор, пока оно непонятно, пока оно удивцяет. Критика удивАяется, наука понимает] 


\section{Nota sobre a tradução}

O objetivo principal da presente tradução do posfácio à Sonata a Kreutzer é apresentar pela primeira vez em português um texto que, como já expusemos, consideramos fundamental dentro do universo tolstoiano. Por outro lado, também é nossa intenção que o trabalho sirva como base para uma pesquisa futura no campo dos estudos da tradução, em que problemas específicos sobre os procedimentos e dificuldades da tradução sejam analisados. Nesse sentido, constitui um trabalho em desenvolvimento.

Por tratar-se de uma publicação em que a tradução é apresentada junto com seu original em língua russa, consideramos importante explicar nesta nota os critérios pelos quais resolvemos a tradução problemática dos termos "внешний - vniêchnii”" (exterior, externo, superficial, aparente) е “определение - opredeliênie" (definição, determinação), que têm um papel importante no texto de Tolstói.

Frequentemente, mas não sempre juntos no posfácio, entende-se, no contexto, que essas palavras vêm a constituir uma unidade semântica que se refere às práticas rituais que as diferentes religiões exigem de seus fiéis. A tradução literal "definição exterior" não remete a esse sentido, e é por isso que essas palavras foram traduzidas, em diferentes momentos, de maneiras diferentes. Em geral, a expressão “внешние определения - vniêchnie opredeliênia» foi traduzida como "práticas superficiais" ou "regras superficiais"; não "externas", nem "aparentes", porque Tolstói faz uma crítica que aponta para a falsidade ou o sem-sentido que existe em muitas práticas religiosas. A definição de "superficial" registrada no Dicionário Aulete Digital como "Que supervaloriza coisas pouco importantes; que julga por aparências; que age sem reflexão (pessoa superficial)", pareceu-nos a mais próxima do sentido que Tolstói queria transmitir. Por isso mesmo, na maioria dos casos em que ele usou o adjetivo "внешний - vniêchnii", optamos pela tradução "superficial", em lugar de "exterior", "externo" ou "aparente". Nisso, nossa tradução difere das outras consultadas. Já o substantivo "определение opredeliênie", quando empregado sem o adjetivo "внешний - vniêchnii", foi geralmente traduzido como "definição".

O trabalho foi realizado a partir da edição das Obras completas de Liev Tolstói em noventa volumes, disponíveis eletronicamente desde $2009^{15}$. Essa edição corresponde à digitalização, concluída no ano 2006, da primeira edição comemorativa das Obras Completas de Liev Tolstói em noventa volumes, realizada entre

15 Ver http://tolstoy.ru/creativity/90-volume-collection-of-the-works/ 
1928 e 1958, e publicada pela editora estatal Khudójestvennaia Literatura. O redator geral da edição comemorativa foi Vladímir Tchertkov, que fora o interlocutor mais próximo de Liev Tolstói nos últimos anos de vida do escritor, e a quem o autor legou a tarefa de cuidar da redação de suas obras.

No processo de cotejo, foram consultadas a tradução para o espanhol, direta do russo, de Irene e Laura Andresco, publicada pela editora Aguilar. Também consultamos a tradução para o inglês do professor Leo Wiener, cujo trabalho de difusão e tradução da literatura russa é considerado precursor nos Estados Unidos.

\section{Posfácio à Sonata a Kreutzer (Liev Tolstói)}

Recebi e continuo recebendo muitas cartas de pessoas desconhecidas, que me pedem para explicar, em palavras simples e claras, o que eu penso acerca do assunto sobre o qual escrevi no relato intitulado "Sonata a Kreutzer". Tentarei fazer isso; quer dizer, explicar em poucas palavras, na medida do possível, a essência daquilo que quis dizer nesse relato, e as conclusões que, na minha opinião, podem ser feitas a partir dele.

Em primeiro lugar, quis dizer que, em nossa sociedade, tem se formado uma sólida convicção, comum a todas as camadas sociais e respaldada por uma ciência falsa, de que as relações sexuais são necessárias para a saúde e que, uma vez que o casamento nem sempre é possível, então a prática do sexo fora dele que não obrigue o homem a nada exceto o pagamento pecuniário - é uma coisa completamente natural e, por isso, deve ser estimulada. Essa convicção tem se tornado a tal ponto comum e consistente que os pais, por conselho médico, organizam a perversão de seus filhos. Os governos, cuja única razão de ser está na preocupação com o bem-estar moral de seus cidadãos, instituem a perversão. Isto é, controlam todo um grupo de mulheres que devem perecer de corpo e alma para a satisfação de necessidades imaginárias dos homens e, assim, pessoas solteiras entregam-se, com a consciência absolutamente tranquila, à perversão.

Então eu queria dizer que isso não é bom, porque não é possível que para garantir a saúde de algumas pessoas, tenha-se que sacrificar o corpo e a alma de outras, da mesma forma que não é possível que, para a saúde de algumas pessoas, seja necessário beber o sangue de outras.

Na minha opinião, a conclusão natural disso tudo é que submeter-se a essa confusão e engano é desnecessário. E para não submeter-se é preciso, em primeiro lugar, não acreditar em doutrinas imorais, por mais amparadas que elas estejam em ciências ilusórias e, em segundo lugar, compreender que manter relações se- 
xuais tais em que as pessoas se desembaracem das possíveis consequências, isto é, dos filhos, ou joguem todo o peso dessas consequências na mulher, ou evitem o possível nascimento das crianças, é um crime contra a mais simples exigência da moral, é uma vileza e, por isso, as pessoas solteiras que não queiram viver na vileza não devem fazer isso.

E para que elas possam conter-se, devem, além de levar um estilo de vida natural, não beber, não se empanturrar, não comer carne nem fugir do trabalho físico exaustivo (não estou falando de fazer ginástica ou de um trabalho de brincadeira), e não devem permitir-se, em seus pensamentos, a possibilidade de relacionar-se com as mulheres dos outros, da mesma forma que qualquer pessoa não admite tal possibilidade entre ela e sua mãe, suas irmãs, parentes ou as mulheres de seus amigos.

Todo homem poderá achar a seu redor uma centena de provas de que a abstinência é possível e menos perigosa para a saúde do que a incontinência.

Essa é a primeira coisa.

Segundo, em nossa sociedade, como consequência da concepção das relações amorosas, tanto como do prazer, não apenas como uma condição indispensável à saúde, mas como um bem poético e sublime da vida, a infidelidade conjugal tem se tornado, em todas as camadas da sociedade (especialmente entre os camponeses, por causa do serviço militar dos soldados ${ }^{16}$ ), o fenômeno mais comum.

E eu suponho que não é bom. A conclusão que se pode tirar é que não se deve fazer isso.

E para não fazê-lo, é preciso mudar a concepção sobre o amor carnal, para que homens e mulheres sejam educados em famílias e por uma opinião pública tais que, antes e depois do casamento, eles não pensem no amor carnal ligado a ele como um estado poético e sublime, como pensam agora, mas que pensem nele como uma humilhante condição animal do homem; e para que a falta ao juramento de fidelidade, dado nas núpcias, seja condenada pela opinião pública,

16 Tolstói fala aqui sobre o serviço dos soldados que não pertencem à categoria de oficiais no exército. Durante a Rússia czarista, o tempo de serviço dos soldados variou, em diferentes épocas, de vitalício, a 25 ou 15 anos. Se o serviço era de 15 anos, isso significava que o soldado tinha que passar 6 anos em qualquer lugar do território do Império aonde fosse destinado, sem direito de se reunir com a família. Depois, podia voltar para seu lugar de origem, passando a formar parte do corpo de reserva por um período de nove anos, o que representava uma grande probabilidade de ser, de novo, enviado para outro destino. Portanto, os soldados eram obrigados a passar longos períodos de tempo afastados de suas esposas e famílias o que, de acordo com o raciocínio de Tolstói, provocou a proliferação da infidelidade. Na época em que Tolstói escreveu $A$ Sonata a Krentz̧er, o serviço era de 6 anos (N. da T.). 
pelo menos tal e como ela condena o incumprimento das obrigações pecuniárias e os enganos no comércio, em lugar de celebrar tudo isso, como se faz hoje, em romances, versos, canções, óperas e assim por diante.

Isso, em segundo lugar.

Terceiro, em nossa sociedade, como consequência, mais uma vez, da falsa significância dada ao amor carnal, o nascimento de crianças perdeu seu sentido e, em lugar de ser o objetivo e justificativa das relações conjugais, tornou-se um empecilho para a continuidade prazerosa das relações amorosas. E é por isso que dentro e fora do casamento, por conselho de servidores da ciência médica, começou a estender-se o uso de meios que privam a mulher da possibilidade de procriar, ou então começou a tornar-se um costume aquilo que antes não existia, e que ainda não existe nas famílias camponesas patriarcais: a continuidade das relações conjugais durante a gravidez e a amamentação.

Suponho que isso não seja bom. Não é bom usar meios contra o nascimento de crianças, primeiro, porque isso libera as pessoas do cuidado e trabalho com crianças, que são a redenção do amor carnal e, segundo, porque isso é o mais próximo que pode existir da ação mais contrária à consciência humana, isto é, o assassinato. E não é boa a incontinência durante a gravidez e a amamentação, porque isso destrói as forças físicas e, o que é mais importante, as forças morais da mulher.

A conclusão que resulta disso tudo é que não se deve fazer isso. E para tanto, é preciso entender que a abstinência, que é condição indispensável da dignidade humana antes do casamento, é ainda mais necessária nele.

Isso em terceiro lugar.

Quarto, que em nossa sociedade, na qual as crianças constituem ora um obstáculo para o prazer, ora um acidente, ou então um certo tipo de prazer, no caso de serem trazidas ao mundo em uma quantidade previamente determinada. Essas crianças são educadas não tendo em vista aquelas tarefas da vida humana que estão diante delas como seres racionais e capazes de amar, mas apenas tendo em vista aqueles prazeres que eles podem proporcionar aos pais. E como consequência disso, as crianças humanas são educadas como os filhotes dos animais, de tal forma que a tarefa principal dos pais consiste não em prepará-los para uma atividade digna da pessoa, mas em alimentá-los da melhor forma possível, aumentar sua estatura, torná-los limpos, brancos ${ }^{17}$, bem alimentados, bonitos (nisso, os pais

17 Tolstói menciona a brancura da pele como característica tida como desejável, porque ela podia ser considerada como um símbolo da condição social, já que eram os camponeses que trabalhavam sob o sol e tinham, portanto, peles queimadas (N. da T.). 
sustentam-se em uma ciência falsa chamada medicina). E nas crianças mimadas, tal como no caso de quaisquer animais empanturrados, manifesta-se de forma artificialmente precoce uma volúpia insuperável que é a causa de terríveis tormentos para essas crianças durante a adolescência. A roupa, a leitura, os espetáculos, a música, a dança, os alimentos doces, toda a organização da vida, as imagens nas embalagens até os romances, novelas e epopeias, atiçam ainda mais essa volúpia e, como consequência disso, os mais terríveis vícios e doenças sexuais tornam-se uma condição comum do crescimento das crianças de ambos os sexos e, com frequência, isso permanece assim até a idade madura.

Eu suponho que isso não é bom. Portanto, a conclusão que se pode tirar é que deve deixar-se de educar os filhos das pessoas como se fossem filhotes de animais e colocar-se, para a educação dos filhos humanos, outros objetivos além da formação de um corpo bonito e bem cuidado.

Isso em quarto lugar.

Quinto, em nossa sociedade, a paixão entre um homem jovem e uma mulher, baseado, de qualquer forma, no amor carnal, tem sido elevado ao nível do mais alto objetivo poético das aspirações humanas; disso dão testemunho toda a arte e a poesia de nossa sociedade, em que os jovens dedicam a melhor época de suas vidas: os homens à observação, à procura e à posse das melhores namoradas, seja sob a forma de relações amorosas ou do casamento, e as mulheres e moças a atrair e aproximar de si os homens, seja por meio de relacionamentos ou do casamento.

E por isso, as melhores forças humanas são gastas em um trabalho não apenas improdutivo, mas prejudicial. Daí provém uma grande parte do insensato luxo de nossa vida; daí também a ociosidade dos homens e a desvergonha das mulheres que não se acanham em se expor, conforme a moda adotada entre aquelas que são evidentemente depravadas, despertando a sensualidade das partes do corpo.

E eu suponho que isso não é bom.

Não é bom porque a realização da união com o ser amado no casamento ou fora dele é um objetivo indigno do ser humano, por mais poetizado que seja, da mesma forma que é indigno do ser humano o objetivo de adquirir para si alimento doce e abundante, mesmo que isso seja apresentado a muitas pessoas como um grande bem.

Portanto, a conclusão que se pode fazer disso é que se deve parar de pensar que o amor carnal é algo especialmente elevado e deve-se entender que um objetivo digno do ser humano (seja servir à humanidade, à pátria, à ciência, à arte, por não falar já em servir a Deus), seja ele qual for, se é que o considerarmos digno, não se atinge por meio da união com o ser amado, seja no casamento ou fora dele; 
pelo contrário, a paixão e a união com o ser amado (por mais que se esforcem em mostrar o contrário em versos e em prosa) nunca ajudam na realização de um objetivo digno do ser humano, mas a dificultam.

Isso em quinto lugar.

Eis o que, em essência, quis dizer e pensei que disse em meu relato. $\mathrm{E}$ pareceu-me que é possível refletir sobre como corrigir esse mal apontado nesses enunciados, com os quais é impossível não concordar.

Pareceu-me que é impossível não concordar com esses enunciados, primeiro porque eles estão, por completo, em conformidade com o progresso da humanidade, indo sempre da licenciosidade para uma maior e maior castidade, e em conformidade também com a consciência moral da sociedade e com nossa consciência, que sempre condena a licenciosidade, ao passo que valoriza a castidade. E segundo, porque esses enunciados são apenas conclusões ineludíveis da doutrina do Evangelho que nós ou professamos ou pelo menos reconhecemos, nem que seja de forma inconsciente, como a base de nossa concepção sobre a moral.

Mas não deu certo.

É verdade que ninguém contesta, de forma direta, a afirmação de que não se deve entregar-se à devassidão antes do casamento, nem depois dele, e que não se deve aniquilar, artificialmente, a procriação, nem fazer das crianças um divertimento, nem colocar as relações amorosas acima de tudo. Em uma palavra, ninguém discute que a castidade é melhor que a licenciosidade. Mas falam: "se o celibato é melhor que o casamento, é então evidente que as pessoas devem fazer o que é melhor. Mas, se as pessoas fizerem isso, então será o fim do gênero humano e, portanto, não pode ser que o ideal do gênero humano seja seu aniquilamento".

E isso para não falar já de que o aniquilamento do gênero humano não é um conceito novo para as pessoas de nosso mundo, mas um dogma de fé para as pessoas religiosas e, para as pessoas de ciência, uma conclusão ineludível da observação do esfriamento do sol. Na objeção disso, há um grande, velho e difundido mal-entendido.

Falam: "se as pessoas atingirem o ideal da castidade absoluta, então elas serão aniquiladas; portanto, esse ideal não está certo". Mas aqueles que falam assim, com ou sem intenção, estão misturando duas coisas diferentes: a regra, o que está prescrito e o ideal.

A castidade não é uma regra ou prescrição, mas um ideal, ou antes, uma das condições dele. E um ideal é ideal só quando sua realização é possível apenas na teoria, no pensamento, quando se imagina que ele pode ser alcançado apenas no infinito, e quando, por isso mesmo, a possibilidade de aproximar-se dele é infinita. 
Se um ideal fosse não apenas alcançável, senão que pudéssemos ainda imaginar sua realização, ele deixaria de ser um ideal. Assim é o ideal de Cristo: o estabelecimento do reino de Deus na terra é um ideal previsto pelos profetas, acerca da chegada do tempo em que as pessoas serão instruídas por Deus, transformarão as espadas em arado, as lanças em foices, o leão ficará deitado com o cordeiro, e quando todos os seres vão se unir pelo amor. Todo o sentido da vida humana está no movimento em direção a esse ideal e, por isso, a aspiração ao ideal cristão em seu conjunto, e à castidade como uma das condições desse ideal, não só inclui a possibilidade da vida, senão que a ausência desse ideal cristão destruiria o movimento para frente e, em consequência, a possibilidade da vida.

A opinião de que o gênero humano será extinto caso as pessoas coloquem todas suas forças em alcançar a castidade é semelhante àquela de que fariam (e estão fazendo) desaparecer o gênero humano se as pessoas, em lugar de lutar pela existência, colocassem todas suas forças em conseguir a materialização do amor pelos amigos e pelos inimigos, e por todos os seres vivos. Tais opiniões são resultado da incompreensão da diferença entre dois métodos do princípio moral.

Assim como existem duas formas de indicar o caminho para um viajante em procura de orientações, existem também dois métodos do princípio moral para aquele que procura a verdade humana. Um método consiste em mostrar à pessoa os objetos que ele deveria encontrar; então, ela se encaminharia para esses objetos. Outro método consiste em mostrar apenas a direção em uma bússola, que a pessoa leva consigo, e na qual ela sempre observa uma direção imutável e, portanto, observa também qualquer desvio dela.

O primeiro método do princípio moral é o das definições superficiais, o das regras: dá-se à pessoa determinados indícios dos atos que deve e dos que não deve realizar:

"Lembra-te do dia de sábado, para santificá-lo, faz a circuncisão, não roubarás, não beberás nem matarás, entrega o dízimo aos pobres, não cometerás adultério, faz as abluções e reza cinco vezes por dia, faz o sinal da cruz, comunga, e assim por diante ${ }^{18}$ ". Tais são os mandamentos das doutrinas religiosas superficiais: bramanista, budista, maometana, judaica e eclesiástica do falsamente chamado cristianismo.

Outro método é mostrar à pessoa a perfeição que ela nunca poderá alcançar, mas cuja aspiração ela reconhece dentro de si: aponta-se para a pessoa o ideal, em

18 Alguns dos mandamentos citados aqui por Tolstói, correspondem ao Decálogo que Deus entregou a Moisés no monte Sinai. Esse decálogo está em Êxodo, 20:1-17; Quanto à circuncisão, que hoje é obrigatória para os judeus, não para os cristãos, o mandado de Deus está em Gênesis 17: 9-14. (N. da T.). 
comparação com o qual ela sempre poderá identificar seu grau de afastamento em relação a ele.

"Amarás o Senhor teu Deus, de todo o teu coração, de toda a tua alma, com toda a tua força e de todo o teu entendimento; e a teu próximo como a ti mesmo"19, e "Portanto, deveis ser perfeitos, como o vosso Pai celeste é perfeito" 20 ".

Tais são os ensinamentos de Cristo.

A comprovação do cumprimento dessas doutrinas religiosas superficiais é a coincidência dos atos com as definições dessas doutrinas, e essa coincidência é possível.

A comprovação do cumprimento dos ensinamentos de Cristo é a consciência do grau de não correspondência com a perfeição ideal. (O grau de proximidade não se vê: vê-se apenas o desvio da perfeição).

A pessoa que professa uma lei superficial é uma pessoa que está à luz de um lampião pendurado em um poste. Ela está sob a luz desse lampião, está na claridade, e não tem mais para onde ir. Quem professa os ensinamentos de Cristo é como uma pessoa que leva um lampião diante de si, numa vara mais ou menos comprida: a luz está sempre diante dessa pessoa, a estimula a ir sempre adiante e revela-lhe permanentemente um espaço novo iluminado que a atrai.

O fariseu agradece a Deus por ele cumprir com tudo. O jovem rico, que também cumpriu com tudo desde a infância, não entende o que lhe falta fazer. E eles não podem pensar de outra forma, porque diante deles não está aquilo que eles poderiam continuar esforçando-se por atingir. O dízimo foi dado, o sábado foi guardado, os pais foram honrados, não cometeram adultério, nem roubaram, nem mataram. O que mais então? Mas já para quem professa a doutrina cristã, chegar até qualquer patamar de perfeição exige a ascensão ao patamar superior, a partir do qual se revela um patamar mais alto, e assim eternamente.

Quem cumpre a lei de Cristo está sempre na posição do publicano. Ele se sente sempre imperfeito, sem poder ver atrás de si aquele caminho que percorreu, vendo sempre aquele por onde tem que ir e que ainda não percorreu.

Nisto consiste a diferença entre os ensinamentos de Cristo e todas as demais doutrinas religiosas: a diferença está não em exigências diversas, mas nos diversos métodos de guiar as pessoas. Cristo não deu nenhuma definição de vida, nunca estabeleceu quaisquer instituições, e sequer estabeleceu casamento algum.

19 Lucas 10:27

20 Mateus 5:48. 
Mas as pessoas, que não entendem as singularidades dos ensinamentos de Cristo, por estar acostumadas com as doutrinas superficiais e por terem o desejo de se sentirem certas (da mesma forma que o fariseu sente que está certo) fizeram da forma uma doutrina superficial de regras, que é contrária a todo o espírito dos ensinamentos de Cristo, e trocaram a verdadeira doutrina do ideal de Cristo por aquela doutrina superficial.

As doutrinas eclesiásticas que chamam a si próprias cristãs colocaram em relação a todas as manifestações da vida, em lugar da doutrina do ideal de Cristo, definições e práticas superficiais que são contrárias ao espírito dessa doutrina. Assim foi feito em relação ao poder, aos tribunais, ao exército, à igreja, à missa, e foi feito também em relação ao casamento. Apesar de cristo nunca ter instituído o casamento - se for o caso de procurar por definições superficiais, ele antes rejeitou o casamento ("Deixa tua esposa, e segue-me") -, as doutrinas eclesiásticas que chamam a si próprias cristãs estabeleceram o casamento como uma instituição cristã; isto é, estabeleceram as condições exteriores pelas quais o amor carnal pode, para o cristão, estar aparentemente livre de pecado, estar absolutamente em conformidade com a lei.

Mas como na verdadeira doutrina cristã não há nenhuma base para a instituição do casamento, aconteceu que as pessoas de nosso mundo se afastaram de uma margem, e não atracaram na outra. Ou seja, em essência, não acreditam na definição eclesiástica do casamento, por sentir que essa instituição não tem alicerce na doutrina cristã e, ao mesmo tempo, não veem diante de si, por estar encoberto na doutrina eclesiástica, o ideal de Cristo da aspiração à castidade absoluta e ficam, em relação ao casamento, sem direção alguma. Daí procede aquilo que, no começo, parece um fenômeno estranho: que os judeus, os maometanos, os budistas tibetanos entre outros, que professam doutrinas religiosas de nível muito mais baixo que o cristianismo, possuem práticas precisas no que se refere ao casamento, aos princípios conjugais e à fidelidade, práticas incomparavelmente mais sólidas do que as que têm os assim chamados cristãos.

Aqueles têm certo concubinato ou poligamia restrito a determinados limites. Já entre nós há um desleixo absoluto e o concubinato, a poligamia e a poliandria, não se submetem a quaisquer regras e ocultam-se sob o aspecto de uma monogamia imaginária.

Só porque, entre uma parte das pessoas que se unem, é realizada uma cerimônia chamada casamento religioso, que o clero realiza a troco de dinheiro, as pessoas de nosso mundo imaginam, inocente ou hipocritamente, que vivem em monogamia. 
Não pode existir o casamento cristão, e nunca existiu, tal como nunca houve nem pode haver liturgia cristã (Mateus 6:5-12; João 4:21), nem mestres, nem padres (Mateus 23:8-10), nem propriedade cristã, nem exército cristão, nem tribunal, nem Estado. Assim foi sempre compreendido pelos cristãos verdadeiros dos primeiros séculos e dos séculos seguintes.

O ideal do cristão é o amor a Deus e ao próximo, é renunciar a si mesmo para servir a Deus e ao próximo; o amor carnal e o casamento, constituem o serviço a si mesmo e, por isso, são, em qualquer caso, um empecilho para servir a Deus e às pessoas, e é por isso que constituem, da ótica cristã, uma queda, um pecado.

O casamento não pode contribuir para servir a Deus e às pessoas, nem sequer no caso em que aquele que se case tenha o objetivo de dar continuidade à espécie humana. Para essas pessoas, em lugar de casar-se para fabricar vidas infantis, seria muito mais fácil sustentar e salvar aqueles milhões de vidas infantis que perecem ao nosso redor por falta, não digo já de alimento espiritual, mas de alimento material.

O único caso em que o cristão poderia casar-se, sem sentimento de queda ou de pecado, seria se ele visse e soubesse que todas as vidas das crianças que existem estão abastecidas.

É possível não aceitar o ensinamento de Cristo, aquele ensinamento do qual está impregnada toda nossa vida e no qual está baseada toda nossa moral, mas, se aceitarmos esse ensinamento, não podemos não reconhecer que ele aponta para um ideal de castidade absoluta.

Pois no Evangelho está dito claramente, e sem possibilidade de qualquer interpretação, que primeiro: o homem casado não deve separar-se de sua esposa, a fim de desposar outra, mas deve viver com aquela a quem se uniu (Mateus 5:3132; 19:8). Segundo: para o homem em geral e, em consequência, tanto o casado como o solteiro, é pecado olhar para a mulher como um objeto para sua satisfação (Mateus 5:28-29). E, terceiro: para o homem solteiro, o melhor mesmo é não se casar, isto é, ser absolutamente casto (Mateus 19:10-12).

Para muitos e muitos, essas ideias parecerão estranhas e até contraditórias, mas não entre si. Essas ideias contradizem toda a nossa vida e, sem querer, aparece a dúvida: quem está certo? Essas ideias ou a vida de milhões de pessoas e a minha própria? Eu experimentei esse mesmo sentimento, e no grau mais alto, quando cheguei às convicções que estou expressando agora: eu não esperava que o curso de meus pensamentos me levasse para onde me levou. Eu me horrorizei de minhas conclusões, não queria acreditar nelas, mas não era possível. E por mais que essas conclusões contradissessem toda a organização de nossa vida, e por 
mais que contradissessem tudo o que eu pensava antes, e até o que eu expressei, eu devia aceitá-las.

"Mas tudo isso são considerações gerais que até podem ser justas, mas têm a ver com os ensinamentos de Cristo e, portanto, são obrigatórias para aqueles que o seguem; mas a vida é a vida, e não se deve, depois de apontar lá na frente o ideal inatingível de Cristo, deixar as pessoas sozinhas em uma das questões mais pungentes, gerais e que provocam as maiores desgraças, apenas com esse ideal, sem nenhuma orientação."

"A pessoa jovem e apaixonada, no começo se deixará arrebatar pelo ideal, mas não suportará e falhará, e sem saber nem conhecer regra alguma, cairá na depravação absoluta!"

É assim que pensam comumente.

“O ideal de Cristo é inatingível, por isso não pode servir-nos como guia de vida; pode-se falar sobre ele, sonhar com ele, mas ele não é aplicável à vida e, por isso, é preciso abandoná-lo. Precisamos não de um ideal, mas de uma regra, um guia à medida de nossas forças, que esteja no nível médio das forças morais de nossa sociedade: por exemplo, um casamento eclesiástico honesto ou até mesmo um casamento não de tudo honesto, em que um dos noivos, no nosso caso, o homem, já tenha se unido a muitas mulheres; ou pelo menos um casamento com possibilidade de divórcio, ou uma união de fato, ou (já que estamos indo por esse caminho) nem que seja, um casamento japonês, com prazo, ou por que não chegar então até as casas de tolerância?”

Falam que isso é melhor que a devassidão da rua. E nisso é que está a desgraça: ao ter-se permitido rebaixar o ideal por causa da própria fraqueza, não se consegue achar aquele limite no qual se deve parar.

Mas esse raciocínio está errado desde o começo. Antes de mais nada, está errado que o ideal de perfeição infinita não possa servir como guia de vida, e que, ao olhar para ele, seja preciso acenar-lhe adeus, afirmando que não preciso desse ideal, já que nunca o alcançarei, ou então rebaixar o ideal até aquele degrau em que quer permanecer minha fraqueza.

Raciocinar assim é a mesma coisa que um navegante falasse para si “já que não posso ir por aquela linha que mostra a bússola, então vou jogá-la fora, ou vou deixar de olhar para ela". Quer dizer, ou jogo fora o ideal, ou vou fixar a agulha da bússola naquele lugar que corresponda, neste minuto, com o caminho de minha embarcação; isto é, rebaixo o ideal à altura de minha fraqueza. O ideal de perfeição dado por Cristo não é um sonho ou o objeto de prédicas retóricas; é, pelo contrário, o mais necessário guia da vida moral das pessoas, acessível a 
todos, como a bússola: um instrumento necessário e acessível para a orientação do navegante; só é preciso acreditar tanto em um como no outro. Não importa em que situação se encontre a pessoa, sempre é suficiente a doutrina do ideal dada por Cristo para obter a indicação mais certeira acerca dos atos que se deve ou não realizar. Mas é preciso acreditar por completo nessa doutrina, e só nessa doutrina, e deixar de acreditar em todas as outras, exatamente como o navegante tem que acreditar na bússola e deixar de espreitar e orientar-se por aquilo que vê pelos lados. É preciso saber orientar-se pela doutrina cristã, da mesma forma que se sabe orientar-se pela bússola, e para isso, o mais importante é que se deve compreender a própria situação e é preciso saber não ter medo de determinar, com exatidão, seu próprio desvio da orientação ideal dada. Não importa em que patamar se encontre a pessoa, sempre existe a possibilidade de aproximar-se do ideal, e não há situação alguma em que se possa dizer que o ideal foi atingido, e em que não se possa aspirar a uma maior aproximação dele. Tal é a aspiração do ser humano ao ideal cristão como um todo e tal também é a aspiração à castidade como uma parte desse ideal. Se imaginarmos, no que se refere à questão sexual, as mais diversas situações das pessoas em que não se observa a abstinência - da infância inocente ao casamento -, em cada patamar entre essas duas situações, a doutrina de Cristo com o ideal que ele apresentou, sempre servirá como guia claro e preciso do que se deve e não se deve fazer em cada um desses patamares.

O que devem fazer o jovem e a moça puros? Permanecer limpos de tentações, e para estar em condições de entregar todas suas forças ao serviço de Deus e das pessoas, devem aspirar a uma castidade de pensamentos e desejos cada vez maior.

O que devem fazer o jovem e a moça que tenham caído em tentação, consumidos por pensamentos de um amor sem objetivo, ou de amor por uma pessoa determinada, que tenham perdido, por causa disso, uma parte conhecida da possibilidade de servir a Deus e às pessoas? A mesma coisa: não se permitir cair, sabendo que a queda não os livrará da tentação, apenas a fortalecerá, e também aspirar a uma castidade cada vez maior para que seja possível um serviço integral a Deus e às pessoas.

O que devem fazer as pessoas quando elas não venceram sua luta e caíram? Não olhar para sua queda como um prazer permitido pela lei, como fazem agora, justificando a queda pelo rito do casamento, ou como um prazer casual que pode ser repetido com outras pessoas, ou como uma desgraça, no caso de a queda acontecer com um desigual e sem rito, mas olhar para essa primeira queda como a única, como início de um casamento indissolúvel. 
O início desse casamento, com todas as consequências decorrentes dele - o nascimento dos filhos - determina, para os que se iniciam nele, uma forma nova, mais limitada de servir a Deus e às demais pessoas. Antes do casamento, as pessoas podem servir a Deus e aos outros de forma imediata, e das mais diversas maneiras; mas o casamento limita seu poder de ação e exige delas dedicar-se à criação e educação dos filhos resultantes desse casamento, para serem futuros servidores de Deus e das pessoas.

$\mathrm{O}$ que devem fazer o homem e a mulher que vivem em casamento e que, produto de sua situação, executam apenas um limitado serviço a Deus e às pessoas por meio da criação e da educação dos filhos?

A mesma coisa: devem aspirar juntos a livrar-se da tentação, à purificação de si próprios e à cessação do pecado, a trocar as relações que impedem o serviço essencial e particular a Deus e às demais pessoas e a trocar o amor carnal pelas relações imaculadas que existem entre irmão e irmã.

Por isso, não é verdade que não possamos guiar-nos pelo ideal de Cristo, porque ele não é nem tão alto, nem tão perfeito, nem tão inatingível. Nós só não podemos guiar-nos por ele, porque mentimos para nós mesmos e enganamo-nos.

Pois se falarmos que devemos possuir regras mais executáveis do que o ideal de Cristo, ou então nós, sem termos atingido esse ideal, cairmos na devassidão, não estamos falando que o ideal de Cristo é alto demais para nós, mas apenas que não acreditamos nele e não queremos condicionar nossos atos a esse ideal.

Se dissermos que, uma vez caídos, cairemos na devassidão, com isso só estamos afirmando que já decidimos, com antecedência, que a queda com alguém que não é nosso igual, não é um pecado, mas uma diversão, uma paixão, que não obrigatoriamente devemos corrigir por meio disso que chamamos casamento. Se entendêssemos que a queda é um pecado que deve e pode ser expiado só por meio de um casamento indissolúvel, e por meio de toda a atividade que deriva da educação dos filhos nascidos desse casamento, então entenderíamos também que a queda não pode, de forma alguma, ser a causa da devassidão.

Isso é a mesma coisa que o lavrador que não considera como lavoura aquela que não deu certo mas, depois de plantar em um segundo e terceiro lugar, considerasse que é uma verdadeira lavoura aquele plantio que vingou. É evidente que tal pessoa estragaria muita terra e sementes e nunca aprenderia a plantar. Tão só coloquem-se o ideal de castidade, considerem que qualquer queda, seja ela qual for, com qualquer pessoa que for, constitui o único e indissolúvel casamento para toda a vida, e será claro que o guia dado por Cristo é, não apenas suficiente, mas o único possível. 
"O homem é fraco, é preciso lhe dar uma tarefa à medida de suas forças", dizem as pessoas. Isso é a mesma coisa que dizer "minhas mãos são fracas e eu não posso traçar uma linha que seja reta, nem sequer a mais curta entre dois pontos e, por isso, para facilitar-me o trabalho, vou pegar como modelo uma curva ou uma linha quebrada, sendo que eu quero traçar uma reta". Quanto mais fraca é a minha mão, mais preciso de um modelo perfeito.

Não se deve, depois de ter reconhecido a doutrina cristã do ideal, fazer de conta que não a conhecemos e trocá-la por normas superficiais. A doutrina cristã do ideal foi revelada à humanidade justamente porque ela pode dirigi-la em sua fase de desenvolvimento atual. A humanidade já viveu um período de normas religiosas superficiais, e ninguém acredita já nelas.

A doutrina cristã do ideal é a única que pode dirigir a humanidade. É impossível, não se deve trocar o ideal de Cristo por regras superficiais, mas é necessário manter esse ideal firme diante de si, em toda a sua pureza e, o mais importante, deve-se acreditar nele.

Àquele que navega à margem poderia se dizer: "atenha-se a essa elevação, a esse promontório, a essa torre", e assim por diante.

Mas chega o tempo em que os navegantes se afastam da margem, e devem e podem servir-lhes de guia apenas os astros inalcançáveis e a bússola, que lhes mostra a direção. Ambos nos foram dados.

\section{Послесловие к “Крейцеровой Сонате” (Аев Никомаевич Томстой)}

Я получиц и получаю много писем от незнакомых мне Аиц, просящих меня объяснить в простых и ясных словах то, что я думаю о предмете написанного мною рассказа под заглавием “Крейцерова соната". Попытаюсь это сАелать, то есть в коротких словах выразить, насколько это возможно, сущность того, что я хоте с сказать в этом рассказе, и тех выводов, которые, по моему мнению, можно слелать из него.

Хотел я сказать, во-первых, то, что в нашем общество сложилось твердое, общее всем сословиям и подАерживаемое Аожной наукой убежление в том, что половое общение есть Аело необходимое Аля зАоровья и что так как женитьба есть Аело не всегда возможное, то и половое общение вне брака, не обязывающее мужчину ни к чему, кроме Аенежной платы, есть Аело совершенно естественное и потому долженствующее быть поощряемым. УбежАение это Ао такой степени стало общим и 
твердым, что родители, по совету врачей, устраивают разврат Аля своих Аетей; правительства, единственный смысл которых состоит в заботе о нравственном благосостоянии своих граждан, учреждают разврат, то есть регулируют целое сословие женщин, Аолженствующих погибать телесно и Аушевно Аля удов етворения мнимых потребностей мужчин, а холостые АюАи с совершенно спокойной совестью предаются разврату.

И вот я хотец сказать, что это нехорошо, потому что не может быть того, чтобы Аля зАоровья одних АюАей можно бы было губить тела и Ауши Аругих мюдей, так же как не может быть того, чтобы Аһя зАоровья одних мюдей нужно было пить кровь Аругих.

Вывод же, который, мне кажется, естественно слелать из этого, тот, что подАаваться этому заблуждению и обману не нужно. А Аля того, чтобы не подАаваться, надо, во-первых, не верить безнравственным учениям, какими бы они ни подАерживались мнимыми науками, а во-вторых, понимать, что вступ ение в такое половое общение, при котором АюАи иАи освобожАают себя от возможных послеАствий его - Аетей, или сваливают всю тяжесть этих последствий на женщину, или предупрежАают возможность рожАения Аетей,_- что такое половое общение есть преступление самого простого требования нравственности, есть подлость, и что потому холостым АюАям, не хотящим жить подло, наАо не Аелать этого.

А^я того же, чтобы они могли воздержаться, они должны, кроме того что вести естественный образ жизни: не пить, не объедаться, не есть мяса и не избегать труда (не гимнастики, а утомляющего, не игрушечного труда), не допускать в мыслях своих возможности общения с чужими женщинами, так же как всякий человек не допускает такой возможности межАу собой и матерью, сестрами, родными, женами друзей.

Аоказательство же того, что воздержание возможно и менее опасно и вредно Аля зАоровья, чем невоздержание, всякий мужчина найдет вокруг себя сотни.

Это первое.

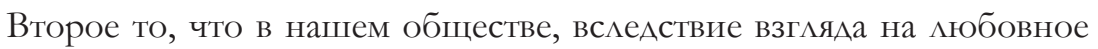
общение не только как на необходимое условие здоровья и на удовольствие, но и как на поэтическое, возвышенное благо жизни, супружеская неверность слелалась во всех слоях общества (в крестьянском особенно, благодаря солАатству) самым обычным явлением.

И я полагаю, что это нехорошо. Вывод же, который вытекает из этого, тот, что этого не надо Аелать. 
А^я того же, чтобы не Аелать этого, надо, чтобы изменился взгляд на плотскую Аюбовь, чтобы мужчины а женщины воспитывались бы в семьях и общественным мнением так, чтобы они и Ао и после женитьбы посмотрели на влюбление и связанную с ним плотскую Аюбовь как на поэтическое и возвышенное состояние, как на это смотрят теперь, а как на унизительное Аля человека животное состояние, и чтобы нарушение обещания верности, Ааваемого в браке, казнилось бы общественным мнением по крайней мере так же, как казнятся им нарушения денежных обязательств и торговые обманы, а не воспевалось бы, как это делается теперь, в романах, стихах, песнях, операх и т. А.

Это второе.

Третье то, что в нашем обществе, вследствие опять того же Аожного значения, которое придано плотской Аюбви, рожАение детей потеряло свой смысл и, вместо того, чтобы быть целью и оправданием супружеских

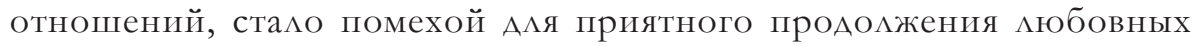
отношений, и что потому и вне брака и в браке, по совету служителей врачебной науки, стало распространяться употребление среАств, Аишающих женщину возможности Аеторождения, или стало входить в обычай и привычку то, чего не было прежде и теперь еще нет в патриархальных крестьянских семьях: продолжение супружеских отношений при беременности и кормлении.

И полагаю я, что это нехорошо. Нехорошо употреблять средства против рожАения Аетей, во-первых, потому, что это освобожАает Аюдей

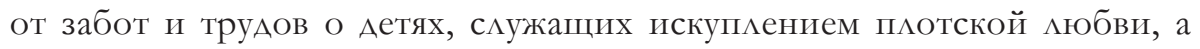
во-вторых, потому, что это почти весьма близкое к самому противному человеческой совести действию-убийству. И нехорошо невоздержание во время беременности и кормления, потому что это губит телесные, а главное — Аушевные силы женщины.

Вывод же, который вытекает из этого, тот, что этого не надо делать. А Аля того, чтобы этого не Аелать, наАо понять, что воздержание, составАяющее необходимое условие человеческого Аостоинства при безбрачном состоянии, еще более обязательно в браке.

Это третье.

Четвертое то, что в нашем обществе, в котором дети представ яются или помехой Аля наслаждения, или несчастной случайностью, или своего рода наслаждением, когда их рожАается вперед определенное количество, эти Аети воспитываются не в виАу тех задач человеческой жизни, которые преАстоят 
им как разумным и мюбящим существам, а только в виАу тех удовольствий, которые они могут доставить родите ям. И что вслеАствие этого Аети АЮАей воспитываются как дети животных, так что главная забота родителей состоит не в том, чтобы приготовить их к достойной человека Аеятельности, а в том (в чем подАерживаются родители Аожной наукой, называемой медициной), чтобы как можно мучше напитать их, увеличить их рост, слелать их чистыми, белыми, сытыми, красивыми (если в низших классах этого не делают, то только по необходимости, а взгляА одни и тог же). И в изнеженных Аетях, как и во всяких перекормленных животных, неестественно рано появАяется непреодолимая чувственность, состав яящая причину страшных мучений этих детей в отроческом возрасте. Наряды, чтения, зрелища, музыка, танцы, слаАкая пища, вся обстановка жизни, от картинок на коробках Ао романов и повестей и поэм, еще более разжигают эту чувственность, и вслеАствие этого самые ужасные половые пороки и болезни делаются обычными условиями вырастания детей обоего пола и часто остаются и в зрелом возрасте.

И я полагаю, что это нехорошо. Вывод же, который можно слелать из этого, тот, что надо перестать воспитывать Аетей Аюдей, как Аетей животных, и Аля воспитания АюАских Аетей поставить себе Аругие цели, кроме красивого, выхоленного тела.

Это четвертое.

Пятое то, что в нашем обществе, где вцюбление межАу молодым

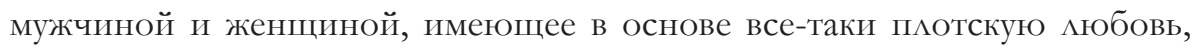
возведено в высшую поэтическую цель стремлений Аюдей, свиАете ьством чего служит все искусство и поэзия нашего общества, молодые Аюди Аучшее время своей жизни посвящают: мужчины на выгАядывание, приискивание

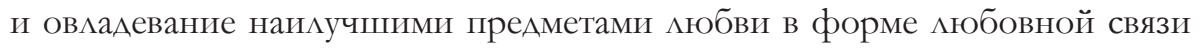
или брака, а женщины и девушки - на заманиванье и вовлечение мужчин в связь или брак.

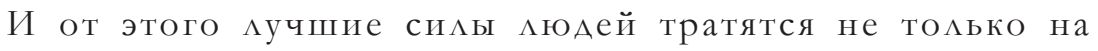
непроизводительную, но на вредную работу. От этого происходит большая часть безумной роскоши нашей жизни, от этого - праздность мужчин и бесстылство женщин, не пренебрегающих выставленным по модам, заимствуемым от заведомо развратных женщин, вызывающих чувственность частей тема.

И я полагаю, что это нехорошо.

Нехорошо это потому, что Аостижение цели соединения в браке или вне брака с предметом мюбви, как бы оно ни было опоэтизировано, есть цель, 
недостойная человека, так же как недостойна человека представцяющаяся многим АюАям высшим благом цель приобретения себе слаАкой и изобиАьной пищи.

Вывод же, который можно слелать из этого, тот, что надо перестать Аумать, что мюбовь плотская есть нечто особенно возвышенное, а надо понять, что цель, Аостойная человека,- служение $и$ человечеству, отечеству, науке, искусству $и$ (не говоря уже о служении богу) — какая бы она ни была, если только мы считаем ее достойной человека, не Аостигается посредством соединения с предметом мюбви в браке или вне его, а что, напротив, вАюбление и соединение с предметом Аюбви (как бы ни старались Аоказывать противное в стихах и прозе) никогда не облегчает Аостижение Аостойной человека цели, по всегда затрудняет его.

Это пятое.

Вот то существенное, что я хоте с сказать и думац, что сказац в своем рассказе. И мне казалось, что можно рассуждать о том, как исправить то зАо, на которое указывали эти положения, но что не согласиться с ними никак нельзя.

Мне казалось, что не согласиться с этими положениями нельзя, во-первых, потому, что положения эти вполне согласны с прогрессом человечества, всегда шедшим от распущенности к большей и большей целомудренности, и с нравственным сознанием общества, с нашей совестью, всегда осужАающей распущенность и ценящей целомудрие; и, во-вторых, потому, что эти положения суть только неизбежные выводы из учения Евангелия, которые мы или исповедуем, или, по крайней мере, хотя и бессознательно, признаем основой наших понятий о нравственности.

Но вышло не так.

Никто, правда, прямо не оспаривает положений о том, что развратничать не надо до брака, не надо и после брака, что не надо искусственно уничтожать деторожления, что не наАо из детей Аелать забавы и не надо ставить Аюбовное соединение выше всего остального,- одним словом, никто не спорит о том, что целомудрие мучше распущенности. Но говорят: "Если безбрачие лучше брака, то очевиАно, что АЮАи Аолжны делать то, что мучше. Если же Аюди сделают это, то род человеческий прекратится, и потому не может быть илеалом рода человеческого уничтожение его”.

Но не говоря уже о том, что уничтожение рода человеческого не есть понятие новое Аля Аюдей нашего мира, а есть Аля религиозных догмат веры, Аля научных же мюдей неизбежный вывод наблюдений об 
охлаждении солнца, в возражении этом есть большое, распространенное и старое недоразумение.

Говорят: “Если АюАи Аостигнут идеала полного целомудрия, то они уничтожаются, и потому идеац этот не верен”. Но те, которые говорят так, умышленно или неумышленно смешивают две разнородные вещи правило, предписание и илеац.

Целомудрие не есть правило или предписание, а илеал или скорее - одно из условий его. А идеац только тогда идеац, когда осуществление его возможно только и идее, в мыс $и$, когАа он преАстав яяется Аостижимым Только в бесконечности и когАа поэтому возможность приближения к нему - бесконечна. Если бы илеал по только мог быть Аостигнут, но мы могАи б представить себе его осуществление, он бы перестац быть илеалом. Таков илеал Христа,- - установление царства бога на земле, илеал, предсказанный еще пророками о том, что наступит время, когда вес мюди будут научены богом, перекуют мечи на орала, копья на серпы, ^ев будет межать с ягненком

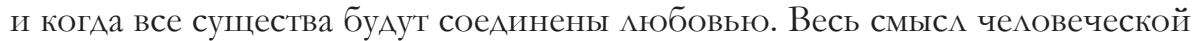
жизни заключается в Авижении по направлению к этому идеалу, и потому стремление к христианскому идеацу во всей его совокупности и к целомуАрию, как к одному из условий этого илеаца, не только не искАючает возможности жизни, по, напротив того, отсутствие этого христианского идеала уничтожило бы движение вперед и, следовательно, возможность жизни.

Суждение о том, что род человеческий прекратится, если АюАи всеми силами будут стремиться к целомудрию, подобно тому, которое сделаАи бы (Аа и Аелают), что род человеческий погибнет, если АюАи, вместо борьбы

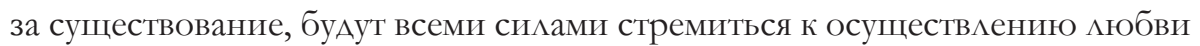
к Арузьям, к врагам, ко всему живущему. Суждения такие вытекают из непонимания разАичия двух приемов нравственного руководства.

Как есть два способа указания пути ищущему, указания путешественнику, так есть и два способа нравственного руководства Аля ищущего правды человека. ОАин способ состоит в том, что человеку указываются предметы, Аолженствующие встретиться ему, и он направ яется по этим предметам.

Аругой способ состоит в том, что человеку дается только направление по компасу, который человек несет с собой и на котором он виАит всегда одно неизменное направцение и потому всякое свое отклонение от него.

Первый способ нравственного руководства есть способ внешних определений, правия: человеку Ааются опрелеленные признака поступков, которые он должен и которых не Аолжен делать. 
“Соблюдай субботу, обрезывайся, не крадь, не пей хмельного, не убивай живого, отАавай десятину бедным, но прелюбодействуй, омывайся и мо-

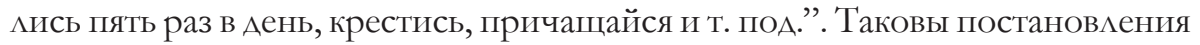
внешних религиозных учений: браминского, будАийского, магометанского, еврейского, церковного, Аожно называемого христианским.

Аругой способ есть способ указания человеку никогда не Аостижимого им совершенства, стремление к которому человек сознает в себе: человеку указывается идеа , по отношению к которому он всегда может видеть степень своего удацения от него.

“Аюби бога твоего всем сердцем, и всею Аушой твоей, и всем разумением твоим и ближнего, как самого себя. Будьте совершенны, как отец ваш небесный”.

Таково учение Христа.

Поверка исполнения внешних религиозных учений есть совпадение поступков с определениями этих учений, и совпадение это возможно.

Поверка исполнения Христова учения есть сознание степени несоответствия с идеальным совершенством. (Степень приближения не виАна: виАно одно откАонение от совершенства.)

Человек, исповедующий внешний закон, есть человек, стоящий в свете фонаря, привешенного к столбу. Он стоит в свете этого фонаря, ему светло, и илти ему Аальше некуда. Человек, исповедующий Христово учение, подобен человеку, несущему фонарь перед собой на более или менее Алинном шесте: свет всегда впереди его и всегда побуждает его илти за собой и вновь открывает ему впереди его новое, вцекущее к себе освещенное пространство.

Фарисей благодарит бога за то, что он исполняет все.

Богатый юноша тоже исполниц все с детства и не понимает, чего может недоставать ему. И они не могут думать иначе; впереди их нет того, к чему бы они могли продолжать стремиться. Аесятина отАана, суббота соблюдена, родители почтены, прелюбодеяния, воровства, убийства - нет. Чего же еще? А^я исповедующего же христианское учение Аостижение всякой ступени совершенства вызывает потребность вступления на высшую ступень, с которой открывается еще высшая, и так без конца.

ИсповеАующий закон Христа всегда в положении мытаря. Он всегда чувствует себя несовершенным, не видя позади себя пути, который он прошел, а видя всегда впереди себя тот путь, по которому еще надо иАти и который он не прошел еще. 
В этом состоит различие учения Христа от всех Аругих религиозных учений, различие, заключающееся не в разАичии требований, а в разАичии способа руководства Аюдей. Христос не АаваА никаких определений жизни, он никогАа не устанав иваА никаких учреждений, никогда не устанав иива $и$ брака. Но Аюди, не понимающие особенности учения Христа, привыкшие к внешним учениям и желающие чувствовать себя правыми, как чувствует себя правым фарисей, противно всему Ауху учения Христа, из буквы его слелаАи внешнее учение правил, называемое церковным христианским учением, и этим учением подменили истинное Христово учение идеала.

Церковные, называющие себя христианскими, учения по отношению ко всем прояв ениям жизни вместо учения идеала Христа поставили внешние определения и правила, противные Ауху учения. Это сделано по отношению власти, суда, войска, церкви, богослужения, это сделано и по отношению брака; несмотря на то, что Христос не только никогда не устанавливац брака, но уж если отыскивать внешние определения, то скорее отрицал его (“оставь жену и иди за мной”), церковные учения, называющие себя христианскими, установили брак как христианское учреждение, то есть определили внешние условия, при которых плотская Аюбовь может Аля христианина будто бы быть безгрешною, вполне законною.

Но так как в истинном христианском учении нет никаких основании Аля учреждения брака, то и вышло то, что Аюди нашего мира от оАного берега отстали и к Аругому не пристали, то есть не верят, в сущности, в церковные определения брака, чувствуя, что это учреждение не имеет оснований в христианском учении, и вместе с тем не видят переА собой закрытого церковным учением илеала Христа, стремления к полному целомудрию и остаются по отношению брака без всякого руководства. От этого-то и происходит то, кажущееся снача^а странным, явление, что у евреев, магометан, Аамаистов и Аругих, признающих религиозные учения гораздо низшего уровня, чем христианское, но имеющих точные внешние определения брака, семейное начало и супружеская верность несравненно тверже, чем у так называемых христиан.

У тех есть определенное наложничество, многоженство, ограниченное известными пределами. У нас же существует полная распущенность и наАожничество, многоженство и многомужество, по подчиненное никаким определениям, скрывающееся под видом воображаемого единобрачия.

Только потому, что наА некоторой частью соединяющихся совершается духовенством за деньги известная церемония, называемая 
церковным браком, Аюди нашего мира наивно или мицемерно воображают, что живут в еАинобрачии.

Христианского брака быть не может и никогда не было, как никогда не было и не может быть ни христианского богослужения (Mф. VI, 5-12; Иоан. IV, 21), ни христианских учителей и отцов (Мф. XXIII, 8-10), ни христианской собственности, ни христианского войска, ни суда, ни государства. Так и понималось это всегда истинными христианами первых и последующих веков.

Илеал христианина есть Аюбовь к богу и ближнему, есть отречение от

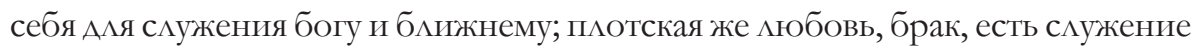

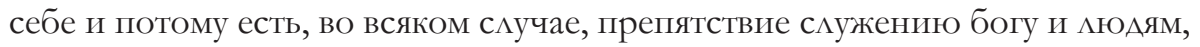
а потому с христианской точки зрения — падение, грех.

Вступление в брак не может содействовать служению богу и Аюдям Ааже в том случае, если бы вступающие в брак имели бы целью продолжение рода человеческого. Таким мюдям, вместо того чтобы вступать в брак Аля произведения детских жизней, гораздо проще подАерживать и спасать те мим^ионы детских жизней, которые гибнут вокруг нас от недостатка не говорю уже Ауховной, но материацьной пищи.

Только в том случае мог бы христианин без сознания падения, греха вступить в брак, если бы он виАел и знал, что все существующие жизни Аетей обеспечены.

Можно не принимать учения Христа, того учения, которым проникнута вся наша жизнь и на котором основана вся наша нравственность, но, принимая это учение, нельзя не признавать того, что оно указывает идеал полного целомуАрия.

В Евангелии ведь сказано ясно и без возможности какого-либо перетолкования - во-первых, то, что женатому не Аолжно разводиться с женой, с тем чтобы взять Аругую, а Аолжно жить с той, с которой раз сошелся (Мф. V, 31-32; XIX, 8); во-вторых, то, что человеку вообще, и, слеловательно, как женатому, так и неженатому, грешно смотреть на женщину как на предмет наслажления (Мф. V, 28-29), и, в-третьих, то, что неженатому мучше не жениться вовсе, то есть быть вполне целомудренным (Мф. XIX, 10-12).

Аля многих и многих мысли эти покажутся странными и даже противоречивыми. И они, Аействительно, противоречивы, но не межАу собой, а мысли эти противоречат всей нашей жизни, и невольно яв яется

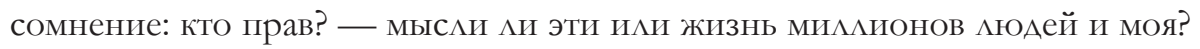
Это самое чувство испытывац и я в сицьнейшей степени, когда приходиА 
к тем убежлениям, которые теперь высказываю: я никак не ожиАац, что ход моих мыслей приведет меня к тому, к чему он привел меня. Я ужасался своим выводам, хотел не верить им, но не верить нельзя было. И как ни противоречат эти выводы всему строю нашей жизни, как ни противоречат тому, что я прежле думац и высказывац даже, я должен был признать их.

“Но все это общие соображения, которые, может быть, и справеАиивы, но относятся к учению Христа и обязательны Аля тех, которые исповедуют его, но жизнь есть жизнь, и нельзя, указав впереди недостижимый идеал Христа, оставить Аюдей в одном из самых жгучих, общих и производящих наибольшие беАствия вопросов с оАним этим иАеалом без всякого руковоАства.

"Молодой, страстный человек сначала увлечется идеалом, но не вылержит, сорвется и, не зная и не признавая никаких правиц, попадет в полный разврат!”

Так рассуждают обыкновенно.

"Христов илеал недостижим, поэтому не может служить нам руководством в жизни; о нем можно говорить, мечтать, но Аля жизни он неприцожим, и потому надо оставить его. Нам нужен не идеац, а правило, руководство, которое было бы по нашим силам, по среднему уровню нравственных сим нашего общества: церковный частный брак или хоть Ааже не совсем честный брак, при котором один из брачущихся, как у нас, мужчина, уже сходился со многими женщинами, или хотя бы брак с возможностью развода, или хотя бы гражАанский, или (иАя по тому же пути) хотя бы японский на срок,почему же не Аойти и Ао Аомов терпимости?"

Говорят, это мучше, чем уличный разврат. В том-то и беда, что, позволив себе принижать илеал по своей слабости, нельзя найти того предела, на котором надо остановиться.

Но ведь это рассуждение с самого начала неверно; неверно прежде всего то, чтобы илеал бесконечного совершенства не мог быть руководством в жизни и чтобы нужно было, гляАя на него, или махнуть рукой, сказав, что он мне не нужен, так как я никогАа не Аостигну его, или принизить идеал Ао тех ступеней, на которых хочется стоять моей слабости.

Рассуждать так — все равно, что мореплавателю сказать себе, что так как я не могу иАти по той Аинии, которую указывает компас, то я выкину компас или перестану смотреть на него, то есть отброшу илеал, или прикреплю стрелку компаса к тому месту, которое будет соответствовать в Аанную минуту ходу моего судна, то есть принижу идеац к моей слабости. ИАеац совершенства, Аанный Христом, не есть мечта или предмет риторических 
проповедей, а есть самое необходимое, всем Аоступное руководство нравственной жизни Аюдей, как компас — необходимое и доступное орудие руководства морехода; только надо верить как в то, так и в другое. В каком бы ни находился человек положении, всегда достаточно учения идеала, Аанного Христом, Аля того, чтобы получить самое верное указание тех поступков, которые Аолжно и не должно совершать. Но надо верить этому учению вполне, этому одному учению, перестать верить во все Аругие, точно так же как надо мореходу верить в компас, перестать приглядываться и руководиться тем, что он видит по сторонам. Надо уметь руководствоваться христианским учением, как уметь руководствоваться компасом, а Аһя этого, главное, надо понимать свое положение, надо уметь не бояться с точностью определять свое отклонение от идеального Аанного направления. На какой бы ступени ни стоя человек, всегда есть Аля него возможность приближения к этому идеалу, и никакое положение Аһя него не может быть таким, в котором бы он мог сказать, что он Аостиг его, и не мог бы стремиться к еще большему приближению. Таково стремление человека к христианскому илеалу вообще и таково же к целомудрию в частности. Если представить себе по отношению полового вопроса самые разАичные положения Аюдей - от невинного детства до брака, - в которых не соблюдается воздержание, на каждой ступени межАу этими Авумя положениями учение Христа с выставляемым им илеалом будет всегАа служить ясным и определенным руководством того, что Аолжно и не Аолжно на кажАой из этих ступеней Аелать человеку.

Что делать чистому юноше, Аевушке? Соблюдать себя чистыми от соблазнов и, Аля того чтобы быть в состоянии все свои силы отАать на служение богу и мюАям, стремиться к большему и большему целомудрию

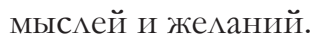

Что делать юноше и девушке, подпавшим соблазнам, поглощенным

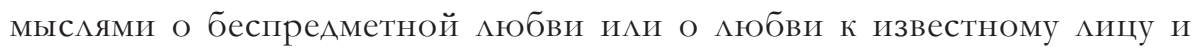
потерявшим от этого известную АОАЮ возможности служить богу и АЮдям? Все то же; не попускать себя на падение, зная, что такое попущение не освободит от соблазна, а только усилит его, и все так же стремиться к большему и большему целомудрию Аля возможности более полного служения богу и АюАям.

Что Аелать Аюдям, когАа они не осилили борьбы и пали? Смотреть на свое падение не как на законное наслаждение, как смотрят теперь, когда оно оправдывается обрядом брака, ни как на случайное удовольствие, которое можно повторять с Аругими, ни как на несчастие, когда падение совершается с неровней и без обряда, а смотреть на это первое падение как на единственное, как на вступление в неразрывный брак. 
Вступление это в брак своим вытекающим из него послеАствием - рождением детей — определяет Аля вступивших в брак новую, более ограниченную форму служения богу и Аюдям. Ао брака человек непосредственно в самых разнообразных формах мог служить богу и Аюдям; вступцение же в брак ограничивает его область деятельности и требует от него возращения и воспитания происходящего от брака потомства, будущих служителей богу и Аюдям.

Что Аелать мужчине и женщине, живущим в браке и исполняющим то ограниченное служение богу и Аюдям, через возращение и воспитание детей, которое вытекает из их положения?

Все то же: стремиться вместе к освобождению от соблазна, очищению себя и прекращению греха, заменой отношений, препятствующих и общему

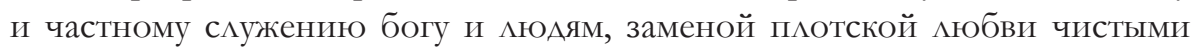
отношениями сестры и брата.

И потому неправда то, что мы не можем руководиться идеалом Христа, потому что он так высок, совершенен и недостижим. Мы не можем руководиться им только потому, что мы сами себе Ажем и обманываем себя.

Ведь если мы говорим, что нужно иметь правила более осуществимые, чем идеал Христа, а то иначе мы, не достигнув идеала Христа, впадем в разврат, мы говорим не то, что Аля нас слишком высок идеал Христа, а только то, что мы в него не верим и не хотим определять своих поступков по этому идеалу.

Говоря, что, раз павши, мы впадем в разврат, мы ведь этим говорим только, что мы вперед уже решили, что паление с неровней не есть грех, а есть забава, увлечение, которое необязательно поправить тем, что мы называем браком. Если же бы мы понимали, что паление есть грех, который Аолжен и может быть искуплен только неразрывностью брака и всей той деятельностью, которая вытекает из воспитания детей, рожденных от брака, то падение никак не могло бы быть причиной впадения в разврат.

А то ведь это все равно, как если бы земледелец не считац посевом тот посев, который не удался ему, а, сея на Аругом и третьем месте, считал бы настоящим посевом тот, который удается ему. ОчевиАно, что такой человек испортил бы много земли и семян и никогда бы не научился сеять. Только поставьте илеалом целомудрие, считайте, что всякое падение кого бы то ни было с кем бы то ни было есть единственный, неразрывный на всю жизнь брак, и будет ясно, что руководство, данное Христом, не только достаточно, но еАинственно возможно. 
“Человек слаб, надо дать ему задачу по силам”,- говорят Аюди. Это все равно, что сказать: "руки мои слабы, и я не могу провести Аинию, которая была бы прямая, то есть кратчайшая межАу Авумя точками, и потому, чтоб облегчить себя, я, желая проводить прямую, возьму за образец себе кривую или моманую”. Чем слабее моя рука, тем нужнее мне совершенный образец.

Нельзя, познав христианское учение идеала, демать так, как будто мы не знаем его, и заменять его внешними определениями. Христианское учение илеала открыто человечеству именно потому, что оно может руководить его в теперешнем возрасте. Человечество уже выжило периол религиозных, внешних определений, и никто уже не верит в них.

Христианское учение илеала есть то еАиное учение, которое может руководить человечеством. Нельзя, не Аолжно заменять идеал Христа внешними правилами, а наАо тверАо Аержать этот идеал переА собой во всей чистоте его и, главное, верить в него.

П^авающему недалеко от берега можно было говорить: “Аержись того возвышения, мыса, башни" и т. п.

Но приходит время, когАа пловцы удалились от берега, и руководством им Аолжны и могут служить только недостижимые светила и компас, показывающий направление. А то и Аругое Аано нам.

\section{Referências}

A Bíblia de Jerusalém. São Paulo: Paulus, 1995.

ARROJO, R. Oficina de traducão. A teoria na Prática. São Paulo, Ática, 1986.

BERNARDINI, Aurora. (Entrevista concedida para o programa da Univesp, Literatura Fundamental n. 90.) https://www.youtube.com/watch?v=iIbMOFobowE Consulta realizada em 30 de setembro de 2017.

CHKLOVSKI, Viktor. "A arte como procedimento". In: Teoria da literatura. Formalistas russos. Porto Alegre: Globo, 1976.

."Iskusstvo kak priem" in: Manifesty Opoiaza. http://www.opojaz.ru/manifests/ kakpriem.html Consulta realizada em 22 de dezembro de 2017.

EIKHENBAUM, Boris. O literature. Raboty raznykkh let. Moskva: Sovietskii pisatel, 1987.

GRIMES, William. "Mulher de Tolstói ganha voz própria". http://www1.folha.uol.com. br/ilustrada/2014/09/1509202-mulher-de-tolstoi-ganha-voz-propria.shtml Consulta realizada em 30 de setembro de 2017. 
MARTINS Marques, Teresa. "Estudo sobre o ciúme - final”. https://www.jornalopcao. com.br/posts/opcao-cultural/estudo-sobre-o-ciume-final Consulta realizada em 30 de setembro de 2017.

NABÓKOV, Vladímir Vladímirovitch. Lições de literatura russa. Edição, tradução e notas de Fredson Bowers. Tradução de Jorio Dauster. São Paulo: Três estrelas, 2015.

RÓNAI, Paulo. A tradução vivida. Rio de Janeiro: Educom, 1976.

. Escola de tradutores. 7 ed. Rio de Janeiro: José Olympio, 2012.

SCHNAIDERMAN, Boris. Leão Tolstói. São Paulo: Brasiliense, 1983.

Posfácio. In: A Sonata a Kreutz̨er. São Paulo: Editora 34, 2013. pp. 107-113.

. Tradução, ato desmedido. São Paulo: Perspectiva, 2011.

SCHNEIDER URSO, Graziela. Versões de Nabókov. Tese apresentada à Faculdade de Filosofia, Letras e Ciências Humanas da Universidade de São Paulo. Departamento de Letras Orientais. Área de concentração: Literatura e Cultura Russa. São Paulo. 2016.

TITAN, Samuel Jr. "“O que quer de mim esta música?”" http://cultura.estadao.com. $\mathrm{br} /$ noticias/artes,o-que-quer-de-mim-esta-musica, 104824 Consulta realizada em 30 de setembro de 2017.

TOLSTÓI, Liev Nikoláevitch. A Sonata a Kreutzer. Tradução de Boris Schnaiderman. São Paulo: Editora 34, 2013.

. "Epilogue to The Kreutzer Sonata". In the translation by Professor Leo Wiener. 1904. http://lol-russ.umn.edu/hpgary/russ $1905 /$ epilogue $\% 20$ to $\% 20$ kreutzer $\% 20$ sonata. htm Consulta realizada em 30 de setembro de 2017.

. Obras. Traducción de Irene y Laura Andresco. Madrid: Aguilar, 1987.

. Polnoe 90-tomnoe sobranie sotchinienii, 2006. (Obras completas em 90 volumes, 2006).

Disponível em: http:/ / tolstoy.ru/creativity/90-volume-collection-of-the-works / Consulta realizada em 02/10/2017.

. Sonata a Krentzer. Traducción de Ricardo San Vicente. Barcelona: Acantilado, 2003. 